\title{
Correction: Production of recombinant Entamoeba histolytica pyruvate phosphate dikinase and its application in a lateral flow dipstick test for amoebic liver abscess
}

\author{
Syazwan Saidin ${ }^{1}$, Muhammad Hafiznur Yunus ${ }^{1}$, Nor Dyana Zakaria' ${ }^{1}$, Khairunisak Abdul Razak ${ }^{2,3}$, Lim Boon Huat ${ }^{4}$, \\ Nurulhasanah Othman ${ }^{1}$ and Rahmah Noordin ${ }^{1 *}$
}

\section{Correction}

After publication of this article [1], it was brought to our attention that we had failed to make it clear that Figures one (Figure 1 here), two (Figure 2 here) and three (Figure 3 here) were put together by grouping elements from different images. The revised figures, in which this grouping has been made explicit in the arrangement, and figure legends, in which the adjustments are clearly stated, are shown below.

We regret any inconvenience that this inaccuracy in the figures in the original manuscript might have caused.

\footnotetext{
Author details

${ }^{1}$ Institute for Research in Molecular Medicine, Universiti Sains Malaysia, Penang 11800, Malaysia. ${ }^{2}$ School of Materials and Mineral Resources Engineering, Engineering Campus, Universiti Sains Malaysia, 14300 Nibong Tebal, Penang, Malaysia. ${ }^{3}$ NanoBiotechnology Research and Innovation (NanoBRI) Institute for Research in Molecular Medicine Universiti Sains Malaysia, Penang 11800, Malaysia. ${ }^{4}$ School of Health Sciences, Universiti Sains Malaysia, Kubang Kerian, Kelantan 16150, Malaysia.
}

Received: 4 September 2014 Accepted: 9 September 2014 Published: 10 November 2014
Reference

1. Saidin S, Yunus MH, Zakaria ND, Razak KA, Huat LB, Othman N, Noordin R: Production of recombinant Entamoeba histolytica pyruvate phosphate dikinase and its application in a lateral flow dipstick test for amoebic liver abscess. BMC Infect Dis 2014, 14:182.

doi:10.1186/1471-2334-14-533

Cite this article as: Saidin et al:: Correction: Production of recombinant Entamoeba histolytica pyruvate phosphate dikinase and its application in a lateral flow dipstick test for amoebic liver abscess. BMC Infectious Diseases 2014 14:533.

\footnotetext{
*Correspondence: rahmah8485@gmail.com

'Institute for Research in Molecular Medicine, Universiti Sains Malaysia, Penang 11800, Malaysia

Full list of author information is available at the end of the article
}

\section{Submit your next manuscript to BioMed Central and take full advantage of: \\ - Convenient online submission \\ - Thorough peer review \\ - No space constraints or color figure charges \\ - Immediate publication on acceptance \\ - Inclusion in PubMed, CAS, Scopus and Google Scholar \\ - Research which is freely available for redistribution



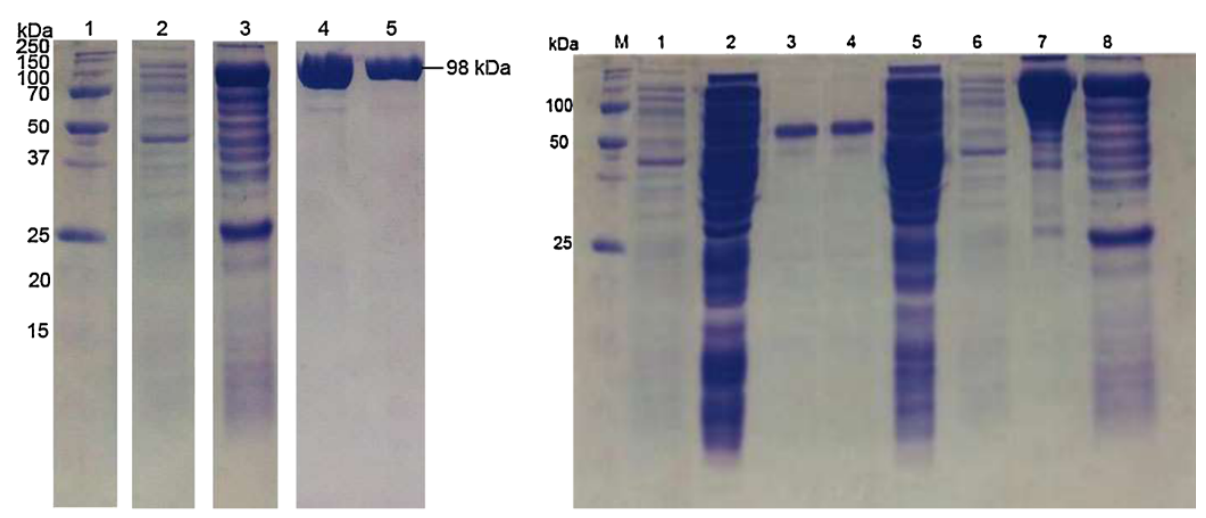

\section{Image $1 \mathrm{~A}$}

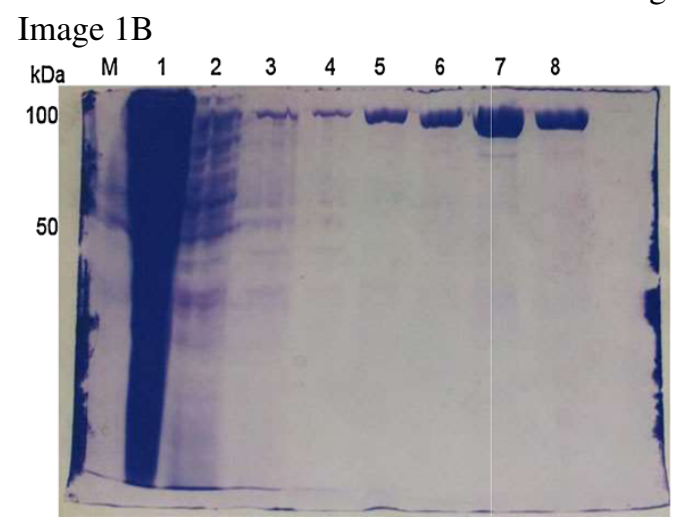

Figure 1 SDS-PAGE analysis shows the purified rPPDK. Lane 1: Precision Plus Protein ${ }^{\text {TM }}$ Unstained Standard Marker (Bio-Rad, USA); Lane 2: Non-induced cell from pET28a/PPDK; Lane 3: Induced cell from pET28a/PPDK; Lanes 4-5: purified rPPDK protein from elution buffer (250 mM imidazole). Arrow indicates the recombinant PPDK protein ( $98 \mathrm{kDa}$ ). Figure one (Figure 1 here) was made by grouping elements from the original Images 1A and 1B as follows: Lanes 1,2 and 3 in Figure one (Figure 1 here) came from lanes M, 6 and 8 respectively in Image 1A; while Lanes 4 and 5 in Figure one (Figure 1 here) came from lanes 7 and 8 respectively in Image 1B. 


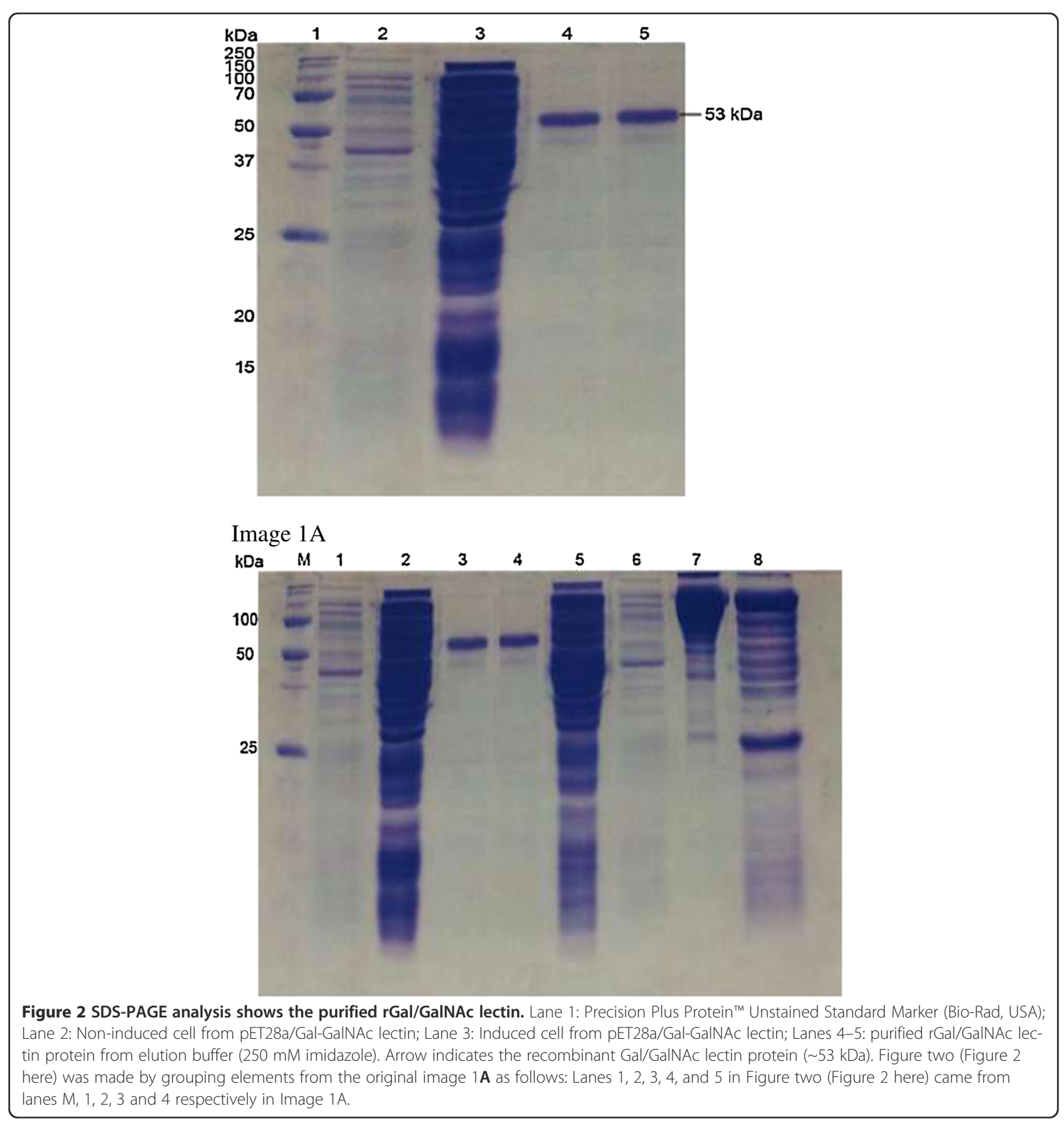




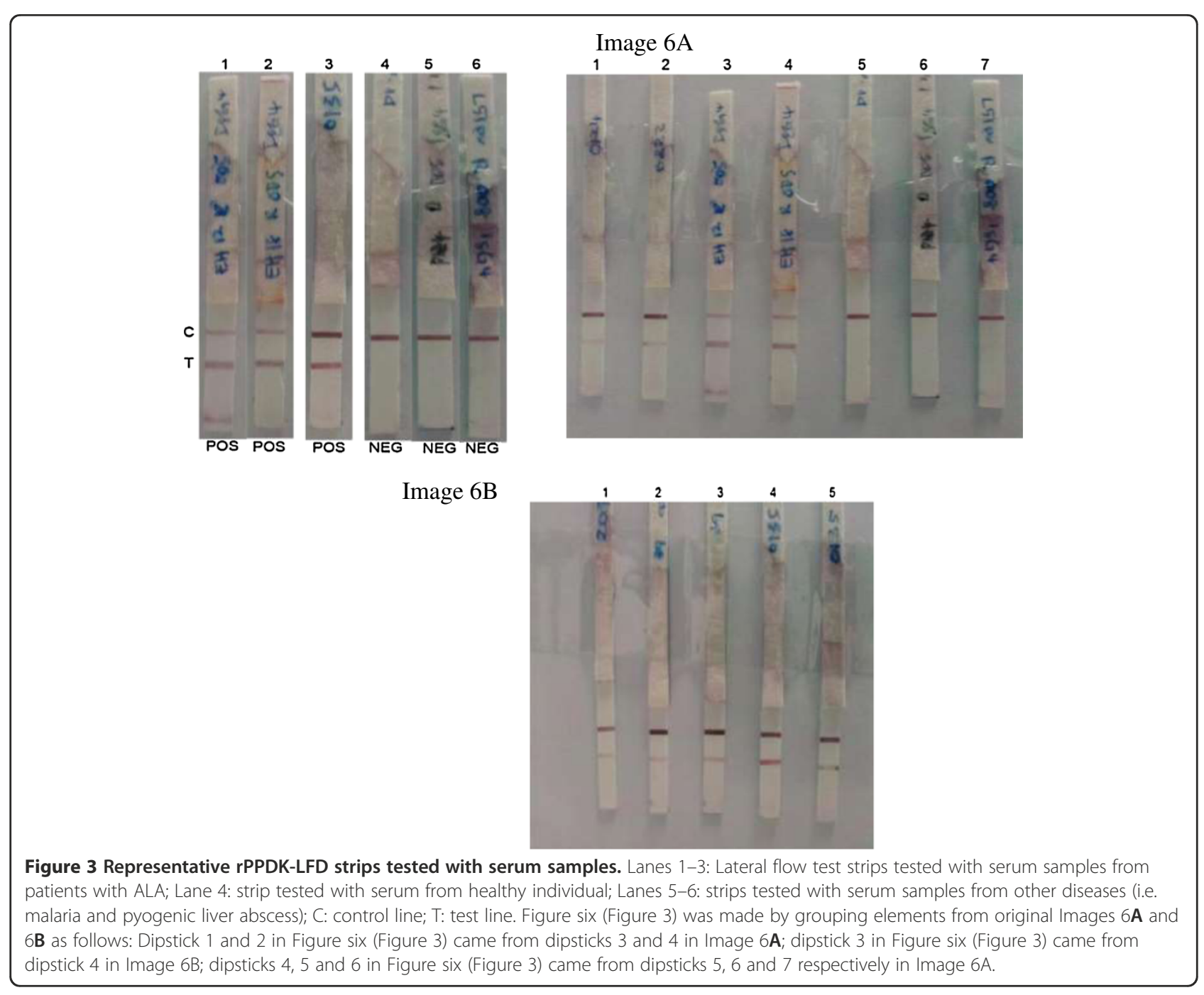

